\title{
Активность глутатионредуктазы при патологических состояниях печени и очистка фермента с применением ионообменной хроматографии для исследования каталитических свойств
}

\author{
Агарков А.А. ${ }^{1}$, Попов С.С. ${ }^{2}$, Крыльский Е.Д. ${ }^{1}$, Шульгин К.К. ${ }^{1}$, \\ Попова Т.Н. ${ }^{1}$, Сафонова О.А. ${ }^{1}$ \\ ${ }^{1}$ ФБОУ ВО «Воронежский государственный университет», Воронеж \\ ${ }^{2}$ ФГБОУ ВО «Воронежский государственный медиџинский университет им. Н.Н. Бурденко» Мини- \\ стерства здравоохранения Российской Федерации, Воронеж
}

Поступила в редакцию 23.07.2016 г.

\begin{abstract}
Выявлено возрастание активности глутатионредуктазы в сыворотке крови больных неалкогольным стеатогепатитом, развивающимся при сахарном диабете 2 типа, и лекарственным гепатитом, а также в сыворотке и печени крыс при экспериментальном токсическом гепатите. Для исследования каталитических свойств фермента была проведена его очистка из печени крыс контрольной группы и животных с индуцированным токсическим гепатитом с применением ионообменной хроматографии. С использованием полученных ферментных препаратов выявлены различия в регуляции активности глутатионредуктазы под действием глюкозо-6-фосфата и рибозо-5-фосфата, что, очевидно, связано с конформационными модификациями молекулы фермента в условиях оксидативного стресса, развивающегося при патологии.
\end{abstract}

Ключевые слова: глутатионредуктаза, токсический гепатит, окислительный стресс, глюко3о-6-фосфат, рибозо-5-фосфат.

\section{The activity of glutathione reductase under liver pathologies and enzyme purification by ion-exchange chromatography for the catalytic properties study}

\author{
Agarkov A.A. ${ }^{1}$, Popov S.S. ${ }^{2}$, Kryl'skiy E.D. ${ }^{1}$, Shul'gin K.K. ${ }^{1}$, \\ Popova T.N. ${ }^{1}$, Safonova O.A. ${ }^{1}$ \\ ${ }^{1}$ FSBEI HE «Voronezh State University», Voronezh \\ ${ }^{2}$ FSBEI HE «Voronezh State Medical University nam. NN Burdenko» the Ministry of Health of the Russian \\ Federation, Voronezh
}

\begin{abstract}
This work is devoted to the analysis of glutathione reductase activity in patients with non-alcoholic steatohepatitis, developing on a background of type 2 diabetes, in patients with drug-induced hepatitis, at an experimental toxic hepatitis in animals, as well as the isolation of the enzyme from rat liver by ion-exchange and gel-chromatography and its regulatory properties study. The blood serum of people, treated in hospital, and healthy persons with normal total and biochemical blood tests was used in the course of the experiment. Besides, the object of the study were control white male laboratory rats and animals with toxic hepatitis modeled by oral administration of carbon tetrachloride. Glutathione reductase activity was determined spectrophotometrically at $340 \mathrm{~nm}$. Reaction rate was assessed by optical density drop as a result of NADPH oxidation. Protein content was determined by the Lowry method. Purification of the enzyme from experimental animals liver included several steps: homogenization of liver sample in a porcelain mortar in 4-fold volume
\end{abstract}


of cooled isolation medium followed by fractionation of proteins with ammonium sulfate; desalting on Sephadex G-25; ion-exchange chromatography on DEAE-cellulose. The results showed an increased glutathione reductase activity in blood serum of patients with impaired liver function. At the same time, the enzyme activity in the blood serum of rats with toxic hepatitis varied similarly and correlated with this parameter in the animals liver. To determine the possibility of modifying of the glutathione reductase conformation under oxidative stress the enzyme purification from the experimental rats liver and study of its regulation by intermediates of the pentose phosphate pathway - main source of NADPH for glutathione reductase reaction, have been carried out. The detected differences of regulatory properties of glutathione reductase in health and under toxic hepatitis suggest that one of the mechanisms of enzyme activity changes at liver pathologies of different etiology may be conformational changes of its molecule. phosphate.

Keywords: glutathione reductase, toxic hepatitis, oxidative stress, glucose-6-phosphate, ribose-5-

\section{Введение}

Согласно современным воззрениям, активные формы кислорода (АФК) играют значительную роль в развитии многих патологических процессов, в том числе заболеваний печени. Вызванные окислительным стрессом нарушения в гепатоцитах, характерные для ряда патологических состояний печени различной этиологии, происходят под действием АФК, генерируемых в реакциях митохондриального и микросомального окисления, а также в реакциях окисления токсических веществ $[1,2]$. Активизация данных процессов при патологии может привести к возникновению в тканях ряда негативных изменений, носящих необратимый характер [3]. К серьезным поражениям печени, возникающим на фоне развития сахарного диабета 2 типа, патогенез которого сопряжен с оксидативным стрессом, относят неалкогольный стеатогепатит (НАСГ). Данная патология часто возникает как осложнение при сахарном диабете 2 типа (СД2) и характеризуется избыточным поступлением свободных жирных кислот в печень, образованием из них триглицеридов, снижением скорости бета-окисления свободных жирных кислот, а также секрецией липидов в кровоток, что способствует формированию жировой дистрофии печени [4]. Интенсификацией свободнорадикального окисления сопровождается также лекарственный гепатит (ЛГ) - состояние, при котором происходит усиленная продукция токсичных соединений в гепатоцитах в результате метаболизма фармакологических веществ под действием системы цитохрома Р450 [5].

Защиту организма от действия свободных радикалов осуществляет антиоксидантная система (АОС), одним из важнейших компонентов которой является глутатионовое звено. Глутатионпероксидаза (ГП), входящая в его состав, катализирует разложение гидропероксидов за счет окисления глутатиона, а глутатионредуктаза (ГР) восстанавливает окисленный глутатион за счет НАДФН [6].

Целью настоящей работы явилась оценка активности ГР у пациентов с НАСГ, развивающимся на фоне СД2, у больных с ЛГ, при экспериментальном токсическом гепатите (ТГ) у животных, а также выделение фермента из печени крыс с использованием ионообменной и гель-хроматографии и исследование его регуляторных свойств.

\section{Эксперимент}

В исследование было включено 131 человек. Из них 65 практически здоровых лиц с нормальными показателями общего и биохимического анализов крови составили контрольную группу, 33 пациентам был поставлен диагноз НАСГ, возникший как осложнение на фоне СД2, 33 человека были больны ЛГ, развивающимся вслед- 
ствие комплексного приема противотуберкулезных препаратов. Диагноз у пациентов был поставлен на основании клинических признаков заболевания, биохимического исследования крови, данных ультразвукового исследования печени. В ходе клинического исследования использовали сыворотку крови больных, находящихся на лечении в стационаре. Кровь для исследования забиралась в пробирки типа «вакутейнер» в утреннее время, натощак, из локтевой вены. Исследования проводились в соответствии с требованиями биомедицинской этики согласно Женевской конвенции о правах человека (1997 г.) и Хельсинской декларации Всемирной медицинской ассоциации (2000 г.) на основании разрешения локального этического комитета, в связи с чем, у всех пациентов было получено письменное добровольное информированное согласие на участие в клиническом исследовании.

Помимо этого, в качестве объекта исследования использовались белые лабораторные крысы-самцы массой 150-200 г. Животные содержались на стандартном режиме вивария. Все манипуляции, проводимые во время эксперимента, соответствовали требованиям международных правил гуманного отношения к животным, отраженных в санитарных правилах по отбору и содержанию экспериментальнобиологических клиник (вивариев) (УК РФ ст. 245). Токсический гепатит у крыс моделировали путем перорального введения четыреххлористого углерода - органоспецифического токсина, обладающего гепатотропным эффектом, в виде $33 \%$ раствора в вазелиновом масле из расчета 64 мкл токсина на 100 г веса животного [7]. Забой животных производили на 4 сутки после введения токсического агента. Контрольным животным вводили соответствующую аликвоту вазелинового масла.

Венозную кровь животных набирали в стеклянную пробирку без антикоагулянта и помещали на 0.5 ч в термостат при температуре $37^{\circ} \mathrm{C}$, затем центрифугировали при $2500 \mathrm{~g}$ в течение 15 мин. Полученную сыворотку использовали для дальнейшего исследования. Печень крысы извлекали под наркозом после многократного перфузирования ледяным физиологическим раствором и использовали для дальнейших исследований.

Активность фермента определяли спектрофотометрически на СФ-56 при 340 нм. О скорости реакции судили по падению оптической плотности в результате окисления НАДФН. Измерение активности проводили в 50 мМ калий-фосфатном буфере (pH=7.4), содержащем 1мМ ЭДТА, 0.80 мМ глутатион окисленный, 0.16 мМ НАДФН. За единицу активности (Е) принимали количество фермента, катализирующее образование 1 мкмоль продукта реакции за 1 мин при $25^{\circ} \mathrm{C}$. Реакцию начинали внесением ферментного препарата. Содержание белка определяли по методу Лоури и соавт. Очистка ГР из печени животных исследуемых групп включала несколько стадий:

1. Для получения гомогената навеску печени гомогенизировали в фарфоровой ступке в 4-х кратном объеме охлажденной среды выделения, содержащей $0.1 \mathrm{MM}$ трис-HCl-буфер (pH=7.6), содержащий 1 мМ ЭДТА, $1 \% \beta$-меркаптоэтанол. Гомогенат фильтровали и центрифугировали при $7000 \mathrm{~g}$ в течение 12 мин. Полученную белковую смесь использовали для фракционирования белков сульфатом аммония. Определение границ высаливания ГР из белкового раствора проводили путём ступенчатого повышения градиента концентрации $\left(\mathrm{NH}_{4}\right)_{2} \mathrm{SO}_{4}$ в гомогенате печени. Кристаллический сульфат аммония добавляли к гомогенату в количестве, соответствующем нижней границе насыщения (40\%). Смесь центрифугировали при $13000 \mathrm{~g}$ в течение 10 мин. Осадок отбрасывали, а к надосадочной жидкости добавляли $\left(\mathrm{NH}_{4}\right)_{2} \mathrm{SO}_{4}$ в количестве, соответствующем верхнему пределу насыщения (70\%). После центрифугирования при $15000 \mathrm{~g}$ в течение 15 мин получали осадок, содержащий ГР. Полученный осадок ресуспендировали в $4 \mathrm{~cm}^{3}$ среды выделения. 
2. Обессоливание на сефадексе G-25. Освобождение белковой смеси от низкомолекулярных примесей осуществляли с помощью гель-фильтрации через колонку с сефадексом G-25 (1.5×20 см) [8]. В качестве элюирующей среды использовали 0.01 М трис-HCl-буфер (pH=7.6), содержащий 0.1 ммоль/дм ${ }^{3}$ ЭДТА, $1 \% \beta$ меркаптоэтанол. Скорость элюции составляла 20-25 cм³/час, её регулирование осуществлялось путем изменения гидростатического давления. Каждую фракцию объемом 2-3 см ${ }^{3}$ анализировали на присутствие ферментативной активности. Фракции, обладающие максимальной ферментативной активностью, объединяли и использовали для дальнейшей очистки.

3. Ионообменная хроматография на ДЭАЭ-целлюлозе. Обессоленный раствор фермента наносили на колонку с ДЭАЭ-целлюлозой $(1.2 \times 13$ см), уравновешенную элюирующей средой, применяемой в ходе очистки на предыдущей стадии. Для очистки ГР использовали ступенчатый градиент концентраций $\mathrm{KCl}$ в элюирующем буфере. Элюирующая среда содержала вышеназванные ингредиенты. В ходе ионообменной хроматографии фермент десорбировался с колонки в ступенчатом градиенте $\mathrm{KCl}$ 50-100 ммоль/дм ${ }^{3}$. Скорость элюции - 30-40 $\mathrm{cm}^{3} /$ ч. Каждую фракцию объемом $1.5-2.0 \mathrm{~cm}^{3}$ анализировали на присутствие ферментативной активности ГР. Все этапы выделения и очистки фермента осуществляли при температуре $0-4{ }^{\circ} \mathrm{C}$.

Опыты проводили в 3-4 кратной биологической повторности, аналитические определения для каждой пробы - в двух повторениях. Данные обрабатывали с использованием стандартных статистических методов [9].

\section{Обсуждение результатов}

Результаты исследований показали, что у пациентов с патологиями печени различной этиологии - НАСГ, возникающем на фоне СД2, и ЛГ, происходило возрастание активности ГР, выраженной в Е/см ${ }^{3}$ сыворотки крови, в 1.3 и 2.2 раза относительно контрольных значений (рис. 1). При ЛГ у больных происходило также возрастание удельной активности фермента в 1.4 раза, в то время как при НАСГ прирост данного показателя был не столь значителен (рис. 1).

В ходе работы было установлено, что активность ГР в сыворотке крови крыс с ТГ изменяется сходным образом. Так, индукция патологии у животных приводила к возрастанию активности фермента, выраженной в $\mathrm{E} / \mathrm{cm}^{3}$, и представленной в Е/мГ белка, в 1.4 и 1.9 раза (рис. 1). Кроме этого, результаты исследования показали, что активность ГР в сыворотке крови крыс с ТГ коррелирует с данным параметром в печени лабораторных животных, где активность фермента, выраженная в Е/Г сырой массы ткани и Е/мг белка увеличивалась в 1.9 и 1.5 раза относительно контроля (табл. 1). Очевидно, наблюдаемые изменения являлись адаптационной реакцией организма, направленной на восстановление глутатиона, используемого в реакциях детоксикации АФК, чрезмерно генерируемых при патологии.

Для выяснения возможности модификации конформации фермента в условиях окислительного стресса была проведена очистка ГР из печени крыс, содержащихся на стандартном режиме вивария, а также животных, у которых индуцировали ТГ. С использованием очищенных препаратов фермента было исследовано влияние интермедиатов пентозо-фосфатного пути (ПФП) - глюкозо-6-фосфата и рибозо-5фосфата, на активность фермента в норме и патологическом состоянии. 

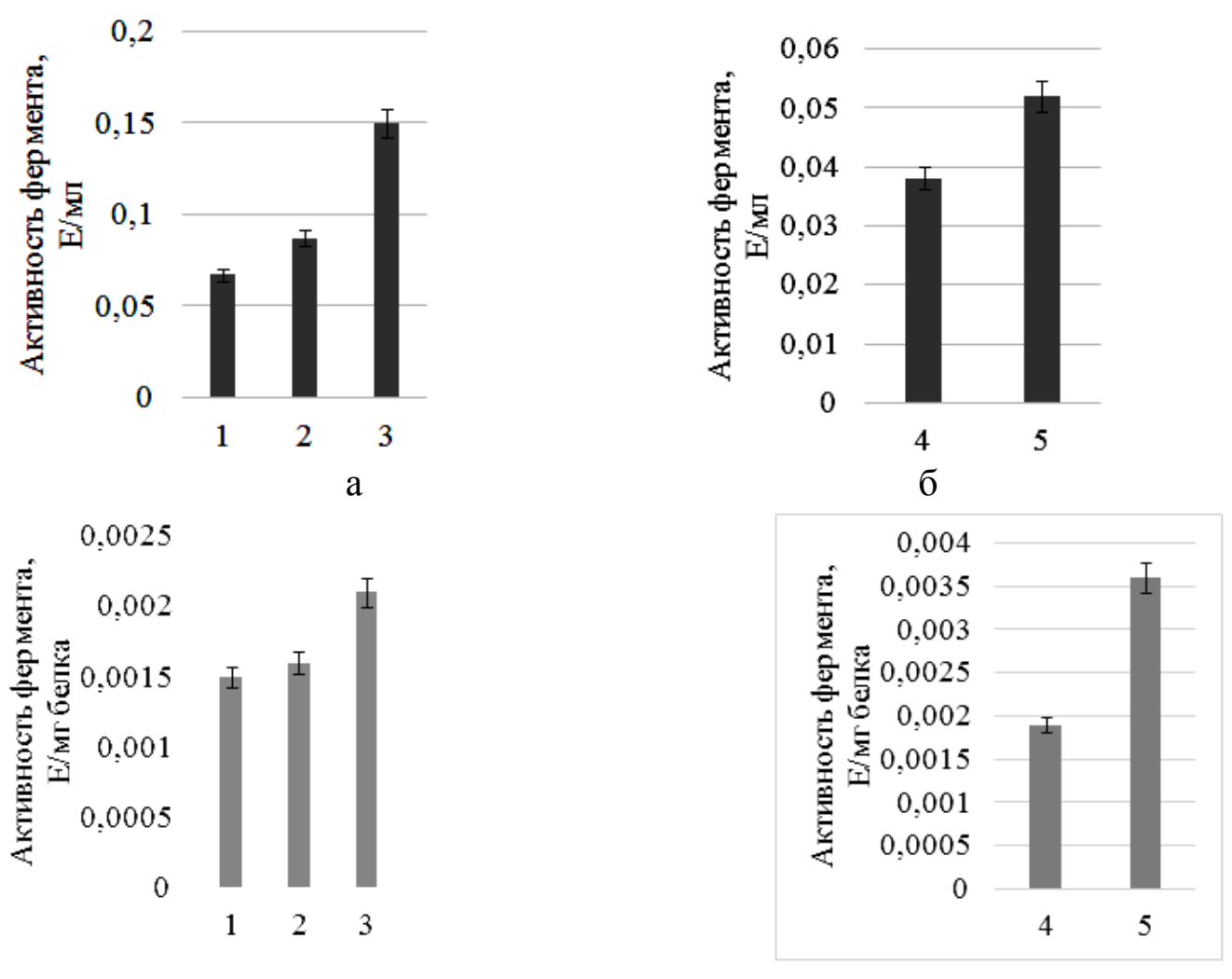

$\Gamma$

Рис. 1. Активность глутатионредуктазы, выраженная в Е/см³ сыворотки крови (а, б), и представленная в виде Е/мг белка (в, г), у людей контрольной группы (1), больных неалкогольным стеатогепатитом (2), лекарственным гепатитом (3), а также крыс контрольной группы (4), и животных с токсическим гепатитом (5).

Таблица 1 Результаты очистки глутатионредуктазы из печени крыс контрольной группы и животных, подвергнутых токсическому гепатиту*

\begin{tabular}{|c|c|c|c|c|c|c|}
\hline Стадия очистки & Условия & $\begin{array}{c}\text { Общая ак- } \\
\text { тивность } \\
\text { Ебщ }\end{array}$ & $\begin{array}{c}\text { Количество } \\
\text { белка, мг }\end{array}$ & $\begin{array}{c}\text { Удельная ак- } \\
\text { тивность, } \\
\text { Е/мг белка }\end{array}$ & $\begin{array}{l}\text { Выход, } \\
\%\end{array}$ & $\begin{array}{l}\text { Степень } \\
\text { очистки }\end{array}$ \\
\hline \multirow{2}{*}{ Гомогенат } & Hop & $2.67 \pm 0.11$ & 243 & $0.011 \pm 0.0004$ & 100 & 1 \\
\hline & Геп & 6.40 & 27 & 0.02 & 10 & 1 \\
\hline \multirow{2}{*}{$\begin{array}{c}\text { Фракционирование } \\
\left(\mathrm{NH}_{4}\right)_{2} \mathrm{SO}_{4}\end{array}$} & $\mathrm{Ho}$ & $2.44 \pm 0.09$ & 19 & 0.01 & 9 & 1.2 \\
\hline & Гепатит & $6.10 \pm 0.27$ & 0.18 & $0.037 \pm 0.0018$ & 95 & 1.6 \\
\hline \multirow{2}{*}{$\begin{array}{l}\text { Хроматография на } \\
\text { сефадексе G-25 }\end{array}$} & Норма & $2.29 \pm 0.08$ & $115.00 \pm 5.77$ & $0.020 \pm 0.0006$ & 86 & 1.82 \\
\hline & Гепатит & $5.44 \pm 0.28$ & $109.00 \pm 5.48$ & $0.050 \pm 0.0028$ & 85 & 2.2 \\
\hline \multirow{2}{*}{$\begin{array}{l}\text { Хроматография на } \\
\text { ДЭАЭ-целлюлозе }\end{array}$} & Норма & $1.21 \pm 0.04$ & $1.98 \pm 0.08$ & $0.600 \pm 0.0271$ & 45 & 54.5 \\
\hline & Гепатит & $1.85 \pm 0.11$ & $1.65 \pm 0.06$ & $1.120 \pm 0.0514$ & 29 & 49 \\
\hline
\end{tabular}

*Примечание: в таблице обсуждаются статистически достоверные различия при $\mathrm{P}<0.05$.

С использованием вышеописанной процедуры очистки были получены ферментные препараты ГР с удельной активностью 0.60 и 1.12 Е/мг белка из печени крыс контрольной группы и животных с ТГ (табл. 1).

В ходе работы было установлено, что в процессе ионообменной хроматографии на колонке с ДЭАЭ-целлюлозой фермент из печени исследуемых групп животных десорбировался в виде одного пика при концентрации $\mathrm{KCl} 100$ мМ (рис. 2). После нанесения ферментного препарата на колонку наслаивали 20 мл среды элюции (0.1 мМ трис-HCl-буфер (pH 7.6), содержащий 1 мМ ЭДТА, $1 \% \beta$-меркаптоэтанол), а 
затем 20 мл 50 мМ раствора $\mathrm{KCl}$ для десорбции сопутствующих белков. Таким способом удалось повысить степень очистки ГР из печени крыс контрольной группы в 30.1 раза, и животных с ТГ - 22.3 раза.

Как известно, одним из основных источников НАДФН для ГР-реакции является (ПФП). В связи с этим, исследование регуляции фермента проводилось с использованием различных концентраций интермедиатов данного метаболитического пути в условиях нормы и при ТГ.

Установлено, что в норме глюкозо-6-фосфат оказывает активирующее действие на ГР в концентрациях до 0.5 мМ (рис. 2). Однако в условиях развития ТГ данный интермедиат активирует фермент при концентрациях до 0.75 мМ. Дальнейшее увеличение концентрации глюкозо-6-фосфата приводило к снижению активности исследуемого фермента из печени экспериментальных групп животных.

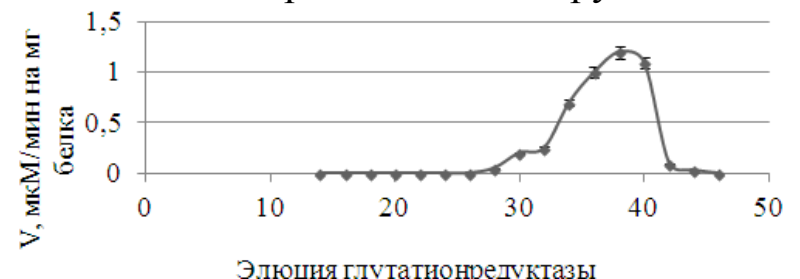

a

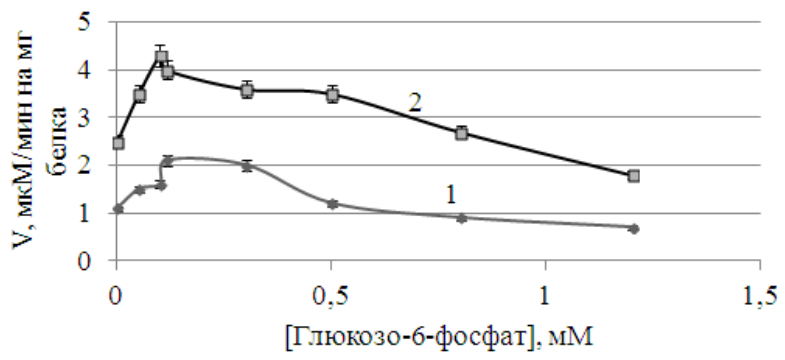

6

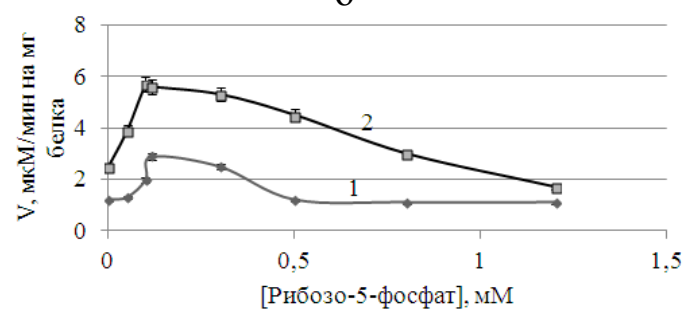

B

Рис. 2. Элюция глутатионредуктазы из печени крыс исследуемых групп животных в ходе хроматографии на ДЭАЭ-целлюлозе (а), и влияние глюкозо-6фосфата (б) и рибозо-5-фосфата (в) на активность фермента в норме (1) и при экспериментальном токсическом гепатите (2)

Анализ влияния рибозо-5-фосфата на активность ГР из печени крыс в норме и при ТГ показал сходный стимулирующий эффект (рис. 2). Наибольшая скорость ферментативной реакции наблюдалась при концентрации интермедиата $0.1 \mathrm{мM}$. При этом в контрольной группе ингибирование ГР под воздействием рибозо-5-фосфата происходило при концентрации интермедиата более 0.5 мМ, в то время как на фермент из печени крыс с ТГ ингибирующее влияние рибозо-5-фосфат оказывал в концентрации свыше 1 мМ. 


\section{Заключение}

Таким образом, с помощью метода ионообменной хроматографии были получены препараты ГР, что позволило установить различия в регуляции данного фермента интермедиатами ПФП в норме и в условиях окислительного стресса, возникающего на фоне ТГ. По-видимому, это могло быть следствием изменения конформации молекулы ГР при интенсификации свободнорадикального окисления, что, однако, не исключает возможность изменения скорости синтеза фермента при развитии патологических состояний печени. Полученные данные позволяют предполагать, что одним из возможных механизмов изменения активности ГР при заболеваниях печени различной этиологии могут являться конформационные модификации молекулы фермента в условиях окислительного стресса.

\section{Работа поддержана стипендией Президента РФ молодым ученым № CП-1606.2015.4.}

\section{Список литературы}

1. Дудник Л.Б., Виксна Л.М., Майоре А.Я. // Вопр. Мед. Хим. 2000. Т. 6. С. 46-52.

2. Park K.I. // Yonsei Med. J. 2000. Vol. 41. No 6. pp. 825-835.

3. Ланкин В.З., Тихадзе А.К., Беленков Ю.Н. // Кардиология. 2004. № 2. С 72-81.

4. Попов С.С., Пашков А.Н., Шульгин К.К. // Экспериментальная и клиническая фармакология. 2015. Т. 78. № 12. С. 6-10.

5. Popov S.S., Pashkov A.N., Shulgin K.K., Agarkov A.A. // Acta Naturae. 2014. Vol. 6. No 21. pp. 110-118.

\section{References}

1. Dudnik L.B., Viksna L.M., Majore A.Ja., Quest. of Med. Chem, 2000, Vol. 6, pp. 46-52.

2. Park K.I., Yonsei Med. J., 2000, Vol. 41, No 6, pp. 825-835.

3. Lankin V.Z., Tihadze A.K., Belenkov Ju.N., Cardiology, 2004, No 2, pp. 72-81.

4. Popov S.S., Pashkov A.N., Shul'gin K.K., Experimental and Clinical Pharmacology, 2015, Vol. 78, No 12, pp. 6-10.

5. Popov S.S., Pashkov A.N., Shul'gin K.K., Agarkov A.A., Acta Naturae, 2014, Vol. 6, No 21, pp. 110-118.

Агарков Александр Алексеевич - к.б.н., доцент кафедры медицинской биохимии и микробиологии Воронежского государственного университета, Воронеж, тел. 8(473)2281160
6. Popov S.S., Shulgin K.K., Popova T.N., Pashkov A.N., Agarkov A.A. de Carvalho, M.A.A.P. // J. Biochem. Mol. Toxicol. 2015. Vol. 29. pp. 449-457.

7. Федорова Н.Ю. Автореф. дис канд. биол. наук. Воронеж, 1999, 24 с.

8. Селеменев В.Ф., Рудаков О.Б., Славинская Г.В., Дроздова Н.В. Пигменты пищевых производств (меланоиды). М. ДеЛи принт. 2008. $246 \mathrm{c}$.

9.Ллойд Э., Ледерман У. Справочник по прикладной статистике. Москва, Финансы и статистика, 1990, 526 с.

6. Popov S.S., Shul'gin K.K., Popova T.N., Pashkov A.N., Agarkov A.A. de Carvalho M.A.A.P., J. Biochem. Mol. Toxicol., 2015, Vol. 29 , pp. $449-457$.

7. Fedorova N.Ju. Syn. diss. cand. biol. nauk. Voronezh, 1999, 24 p.

8. Selemenev V.F., Rudakov O.B., Slavinskaya G.V., Drozdova N.V. Pigments Food Production (melanoidy), M., New Delhi print. $2008,246 \mathrm{p}$.

9. Lloid E., Lederman U. Spravochnik po prikladnoj statistike. M., Finansy i statistika Publ., 1990, $526 \mathrm{p}$.

Agarkov Aleksandr A. - Ph.D (biology), associate prof., Department of medical biochemistry and microbiology, Voronezh State University, Voronezh 
Попов Сергей Сергеевич - к.м.н., доцент, доцент кафедры госпитальной терапии и эндокринологии Воронежского государственного медицинского университета им. Н.Н. Бурденко, Воронеж

Крыльский Евгений Дмитриевич - аспирант кафедры медицинской биохимии и микробиологии Воронежского государственного университета, Воронеж

Шульгин Константин Константинович к.б.н., доцент кафедры медицинской биохимии и микробиологии Воронежского государственного университета, Воронеж

Попова Татьяна Николаевна - д.б.н., профессор, зав. кафедрой медицинской биохимии и микробиологии Воронежского государственного университета, Воронеж

Сафонова Ольга Анатольевна - к.б.н., доцент, доцент кафедры медицинской биохимии и микробиологии Воронежского государственного университета, Воронеж
Popov Sergey S. - Ph.D (medicine), associate prof., Department of hospital therapy and endocrinology, Voronezh State Medical University nam. NN Burdenko, Voronezh

Kryl'skiy Evgenij D. - the postgraduate student, Department of medical biochemistry and microbiology, Voronezh State University, Voronezh, Email: evgenij.krylsky@yandex.ru

Shul'gin Konstantin K. - Ph.D (biology), associate prof., Department of medical biochemistry and microbiology, Voronezh State University, Voronezh

Popova Tatyana N. - prof., grand Ph.D (biology), Department of medical biochemistry and microbiology, Voronezh State University, Voronezh

Safonova Olga A. - Ph.D (biology), associate prof., Department of medical biochemistry and microbiology, Voronezh State University, Voronezh 